\title{
INVESTIGATING ALTERNATIVE POWER GENERATION STRATEGIES FOR LOCAL MUNICIPALITIES THAT ARE TIED TO THE NATIONAL GRID
}

\author{
Bonolo Patricia Tshetlhe \\ Department of Electrical, Electronic and Computer Engineering, \\ Central University of Technology, Free State Private Bag X20539, Bloemfontein, (South Africa). \\ E-mail: tshetlhebt@gmail.com ORCID: https://orcid.org/0000-0002-8468-4694
}

Arthur James Swart

Central University of Technology, Free State, Bloemfontein, (South Africa). E-mail: aswart@cut.ac.za ORCID: https://orcid.org/0000-0001-5906-2896

Phillip Koko

Central University of Technology, Free State, Bloemfontein, (South Africa). E-mail: skoko@cut.ac.za ORCID: https://orcid.org/0000-0001-8954-0588

Recepción: 07/06/2021 Aceptación: 31/08/2021 Publicación: 14/09/2021

\section{Citación sugerida:}

Tshetlhe, B. P., Swart, A. J., y Koko, P. (2021). Investigating alternative power generation strategies for local municipalities that are tied to the national grid. 3C Tecnología. Glosas de innovación aplicadas a la pyme, 10(3), 39-55. https://doi.org/10.17993/3ctecno/2021.v10n3e39.39-55 


\section{ABSTRACT}

Escalating electrical energy usage and costs over the past few years has resulted in large utility bill expenses that municipalities are struggling to pay-off to National Energy Suppliers. Furthermore, some energy suppliers are struggling to meet the demand for more energy due to a variety of factors. The challenge therefore exists in identifying viable alternative power generation strategies for local municipalities to reduce their current electrical energy expenses or to provide limited power to their community when disconnected from the National Grid. An environmentally friendly renewable energy strategy method could be used to supplement the current energy requirements of a municipality during months of high energy demand. The main focus of this study will be on a small town in the Free State province of South Africa, called Koffiefontein. A battery-based solar PV system was designed in the Homer software and chosen as the renewable energy strategy to supplement the current energy needs of Koffiefontein due to its performance and cost effectiveness. The initial implementation cost of the system is \$42995649.95. The cost of energy for the PV system suggested for Koffiefontein houses is $\$ 0.40 / \mathrm{kWh}$ with the yearly electricity production of $27661 \mathrm{kWh}$. The payback period of the system is 45.3 years. The municipality needs to consider installing battery-based solar PV system to supply businesses in Koffiefontein during their high demanding hours and during load shedding as the system indicates an affordable cost of energy with high yearly production.

\section{KEYWORDS}

Solar PV Systems, Wind Turbine Systems, Load Shedding, Energy Audit. 


\section{INTRODUCTION}

Electricity supply in South Africa (SA) has long been the domain of the National Energy Supplier, called Eskom (Nehrir, 2011). Eskom supplies 96\% of electricity in SA (Alfreds, 2018). Eskom and municipalities both distribute electricity to consumers; the distribution function is shared between them (Eskom, 2018). It is a major source of income for municipalities that supply electricity to households and businesses (South African Government, 2011). Eskom supplies the licensed municipalities in bulk at a pre-determined tariff, then the municipality re-sells electricity to the end users within their municipal borders at a markup. There are municipalities which are struggling to pay Eskom the amount of money owed due to low revenue collection from electricity e.g. Matjabeng local Municipality is currently indebted to Eskom for almost 2 Billion Rand (\$ 105654 156), part of which has been outstanding and in escalation since October 2007 (Eskom, 2018). Energy autonomy is an option being seriously considered now more than ever before and for good reasons.

The main aim of this study is to investigate alternative power generation strategies for local municipalities in order to enable more autonomy and that can help to reduce the pressure placed on the National Gird. This paper will discuss the importance of renewable energy resources. Data requirements for Homer will be analyzed and simulation results of two main strategies (solar and wind) will be presented. The conclusions end the discussion.

\subsection{CONTEXT THAT NECESSITATES ALTERNATIVE STRATEGIES}

The demand for power keeps growing at an alarming rate while supply trails behind. This leads to the implementation of load shedding initiatives to keep the country illuminated. When there is not enough electricity available to meet the demand for all Eskom customers, it could be necessary to interrupt supply to certain areas; this is called load shedding (Davidson, 2014). Load shedding is defined as a coordinated set of controls that decreases the electric load in one part of the system to restore the overall system back to its normal operation conditions (Swart, 2018). 
In November 2007, load shedding hit SA for the first time, disrupting businesses, closing mining operations and affecting households (Coetze \& Mart-Mari, 2016). The national power grid again came under severe constrains during the 2013/2014 summer maintenance program, requiring Eskom to implement load shedding again. Eskom implemented 99 days of load shedding in 2015, causing a decrease in manufacturing and mining output, dragging down economic growth (Coetze \& Mart-Mari, 2016).

Renewable and clean alternative power generation technologies can play an important role in mitigating these occurrences of load shedding. Increased global public awareness of the need for environmental protection and desire for less dependence on fossil fuels for energy production is also required (Nehrir, 2011). SA has to consider alternative power generation strategies, such as solar and wind energies, to keep up with the growing demand and to enable a better level of sustainability (Nehrir, 2011).

SA has one of the best solar irradiances in the world and experiences some of the highest levels of yearly horizontal solar irradiation globally. The average daily solar radiation in SA is between 4.5 and 6.5 $\mathrm{kWh} / \mathrm{m} 2 /$ day (Niselow, 2019). In terms of SA's theoretical wind potential, research from the Council for Scientific and Industrial Research suggest that to generate the equivalent of SA's current electricity demand, only $0.6 \%$ of the available SA's land mass would have to be dedicated to wind farms (Nehrir, 2011). The two main alternative strategies for this study focus on the use of wind and solar farms as possible supplements to the current energy needs of one town in the Letsemeng Local Municipality in the Free State Province of SA.

\section{METHOD}

This research is focused on one town in the Letsemeng Local Municipality, located in the Free State Province of SA, which is Koffiefontein. The objective of this research is to:

1. Obtain the energy usage bills from Eskom to determine what energy needs to be supplemented. 
2. Determine the number of homes/businesses that contribute to this bill, to determine if both or just one can be supplemented.

3. Recommend an appropriate renewable energy strategy (solar or wind) for the identified municipality.

The energy bills from Eskom to the municipality are obtained at the main meter of Eskom in each town. This bill indicates power consumption of the municipality for a certain month and the Notified Maximum Demand. For winter months, the energy is classified into two groups: the low and high season energy and they differ in charges.

An energy audit is conducted to determine the energy required by homes and businesses in the two towns. Audit levels clearly differ in respect of their set of objectives, scope of tasks and powers and the related tools (Palyi, 2015). A novel approach would involve using Google Maps as a tool to determine the number of households and businesses that contribute to the present energy demand. This forms a basic level audit.

Household neighborhoods are identified by swimming pools, sports grounds and schools. Businesses would be identified by the nearby presence of government departments of public buildings. This is then correlated to the amount of electrical energy that was sold to residential and industrial businesses for the past year. This helps to identify months of high energy usage. This data is then correlated to the weather data (solar radiance and wind speed per month) that has been obtained for the past 10 years in order to determine if a solar or wind farm is more suitable. After comparing the annual weather data with the monthly energy consumption from the municipality, an alternative power generation method can be suggested. Supplementary energy could be provided during high demanding hours of businesses and when government departments and schools are operative.

The Homer program can be used for simulating the output power of the two strategies with the given weather data. This software has been used both to analyze the off-grid electrification issues in 
the developed as well as developing countries (Sen, 2013). Solar radiation data, wind speed data and electricity consumption of the municipality needs to be used as input data to Homer. A cost analysis and payback period are then computed.

\subsection{DATA REQUIREMENTS}

During the audit, the following identification criteria was used: household neighborhoods were identified by the presence of a school (sports ground or label indication). Businesses were identified by the presence of a government building or label indication. The results of the audit indicated that Koffiefontein consist of 2038 houses and 113 businesses, with the houses consuming more energy than businesses.

The results of the audit were correlated to the municipal electricity sales that are shown in Figure 1. June 2016 has the highest energy consumption for Koffiefontein houses, therefore the energy consumption obtained for June 2016 is used to create a daily load profile for Homer. For the year 2016, Koffiefontein had a total revenue collection of R 9277146 (\$ 613 767), of which R 6893384 (\$456 059) was collected from houses and R 2383761 (\$157 707) was collected from businesses.

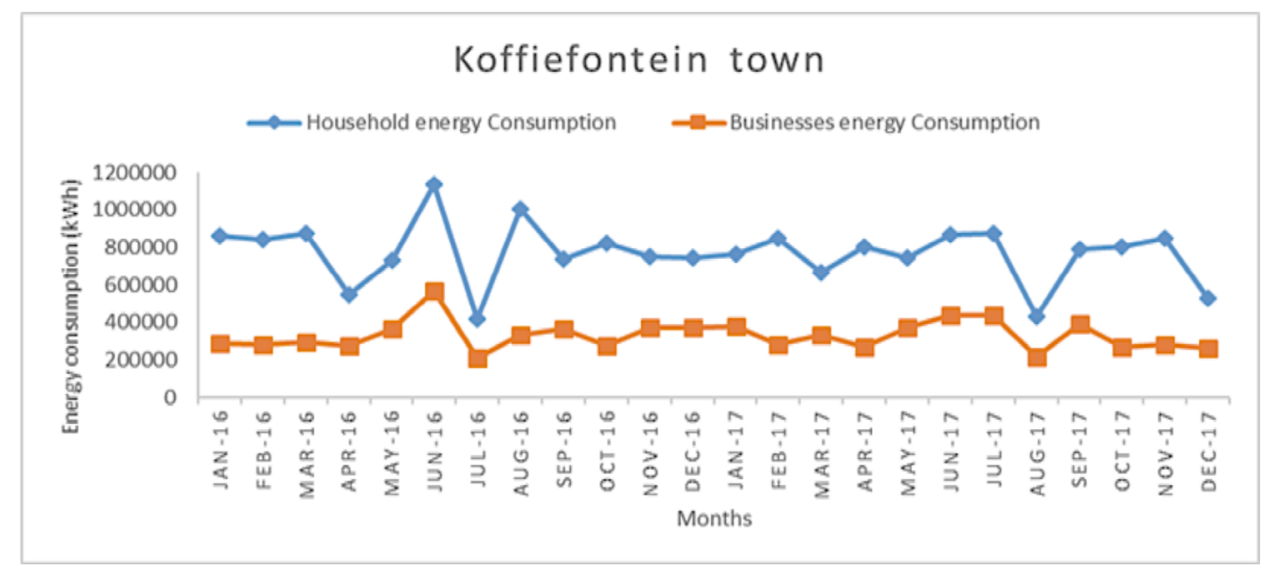

Figure 1. Total energy consumption of Koffiefontein town.

Source: own elaboration. 
Energy consumption data obtained from the municipality is in months. To convert the energy consumption to daily consumption it was firstly converted to weekly consumption using equation 1.

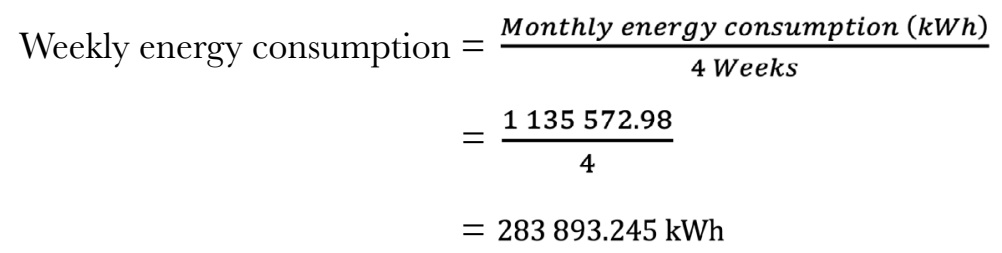

The total daily energy consumption is then $40556.171 \mathrm{kWh}$ (weekly divide 7 ) and the daily energy consumption per house is then $19.9 \mathrm{kWh}$ (total daily divide 2038). The daily usage of an average household in Koffiefontein town is used to design a 24-hour electricity consumption required as input data for Homer. The load peak demand for the average house in Koffiefontein is $2 \mathrm{~kW}$. When summing the hourly usage for 24 hours, as indicated in Figure 2, then a total daily energy consumption of 19.9 $\mathrm{kWh}$ is obtained. The peak load requirement decides the size, structure and architecture of the proposed system (Belu, 2014). The size of the alternative energy system should consider the month of June 2016 which is the highest energy consuming month for Koffiefontein. Homer software is used to design a system for 1 house in Koffiefontein town. The results can then be scaled to cover all 2038 houses in Koffiefontein.

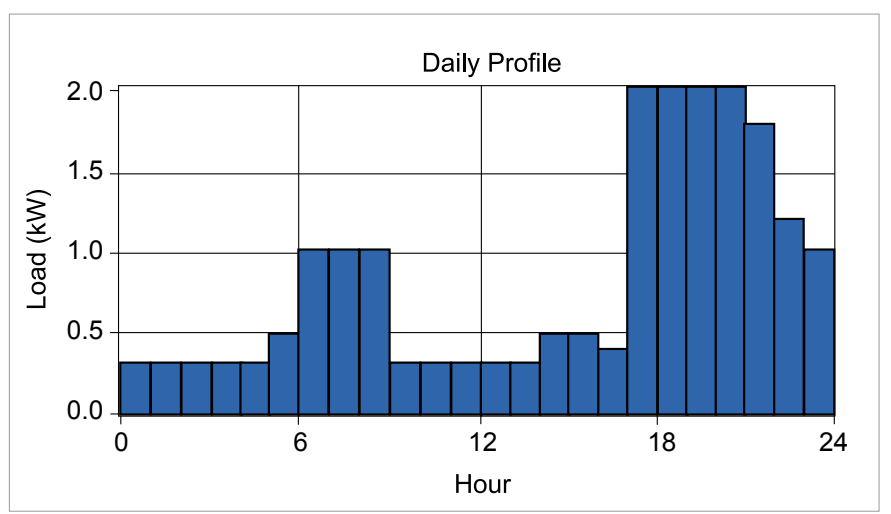

Figure 2. Hourly energy consumption of an average sized home in Koffiefontein.

Source: own elaboration. 


\section{RESULTS}

\subsection{RESULTS FOR A SOLAR ENERGY SYSTEM}

Solar radiation data is one of the important inputs that is required by Homer when doing simulations for solar PV systems. Figure 3 indicates the solar radiation data that was obtained from the Pulida solar plant located about 20 minutes' drive outside Jacobsdal, a small rural village in the Free State Province of South Africa. This data was collected in Jacobsdal town which is the nearest town to Koffiefontein because there is no solar plant in Koffiefontein. The scaled annual average of the site is indicated to be $6.06 \mathrm{kWh} / \mathrm{m}^{2} / \mathrm{d}$, this value is calculated automatically by Homer.

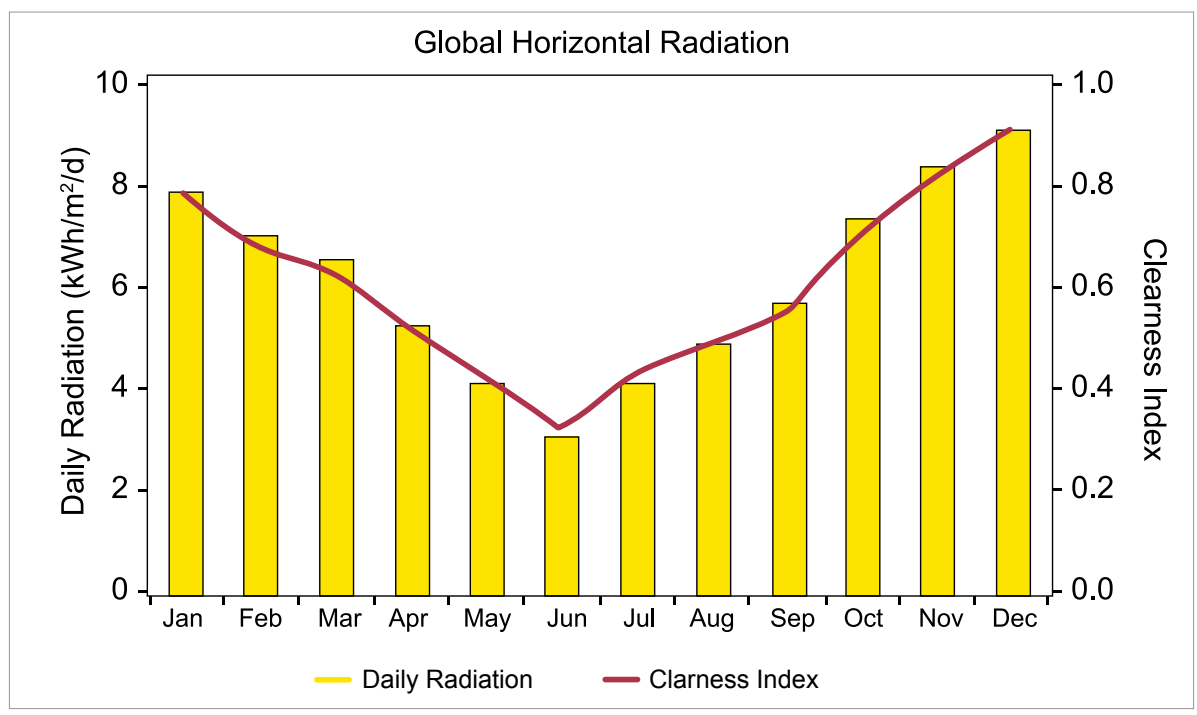

Figure 3. Solar radiation graph from HOMER based on the data from Jacobsdal.

Source: own elaboration.

Figure 4 shows the proposed battery-based solar PV system to be used to supply an averaged sized home in Koffiefontein. The PV panels have no tracking device and they were modelled with a slope of 
30 degree. The following individual PV panel sizes were considered in integer steps of one $\mathrm{kW}$ from 1-20 kW. The price of a $1 \mathrm{~kW}$ PV panel was considered to be R 7592 (\$ 210 96). The operation and maintenance $(\mathrm{O} \& \mathrm{M})$ cost of the solar PV panels is assumed to be $1.56 \%$ of the capital cost (Garni, 2017). 58 Ah Trojan T-105 battery was considered for this study. The individual sizes were considered in integer steps of one Ah from 1-40 Ah. The price of the battery was taken to be R 2894 (\$189) with the O\&M cost assumed to be $2 \%$ of the capital cost of the battery (Koko, 2014).

A 5-kW inverter was considered to meet the peak demand of the load. The price of the pure sine wave inverter which is a Bi-Directional designed to obtain optimum inverter AC power from an installed DC battery system is found to be $\mathrm{R} 29599$ (\$ 1 958). The O\&M cost is assumed to be 1\% of the capital cost (Koko, 2014). The typical lifespan of the converter is considered to be 15 years (Koko, 2014). The load demand of the studied averaged sized home is found to be $20 \mathrm{kWh} /$ day, as obtained from the municipality. During Homer simulation, the daily random variation of $10 \%$ was considered since it is impossible for the daily load demand to be constant throughout the year. The system indicated in Figure 4 has an electricity production of 27,661 kWh/year as indicated in Figure 5.

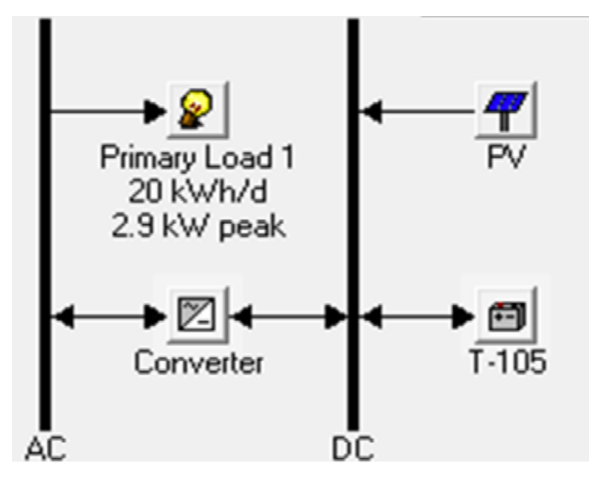

Figure 4. Proposed solar PV system to supply 1 house in Koffiefontein.

Source: own elaboration. 


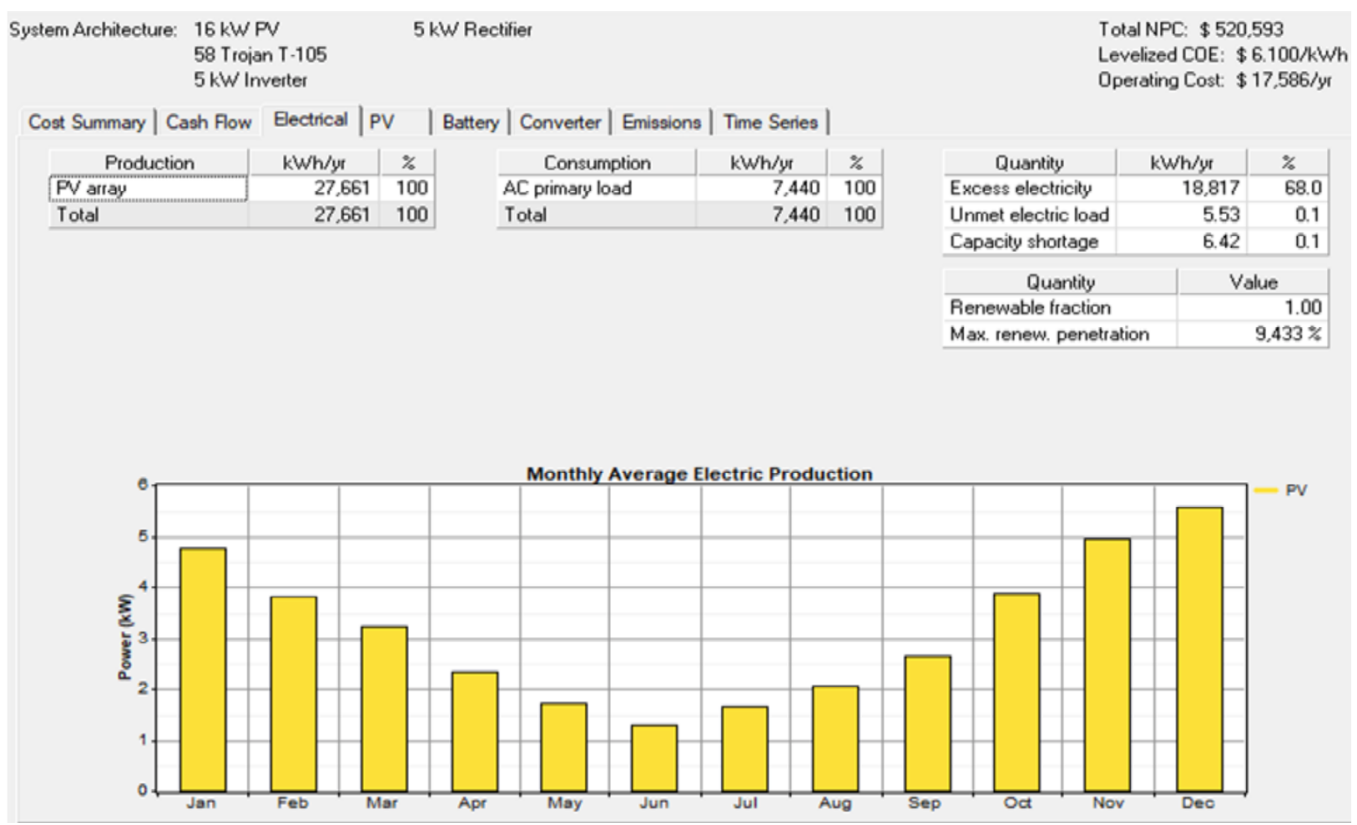

Figure 5. Yearly electricity production.

Source: own elaboration.

This system consists of a PV of size $16 \mathrm{~kW}, 58$ Trojan T- 105 battery which are connected in 2 batteries per string. Excess electricity for this system is $18,817 \mathrm{kWh} /$ year. This is found to be $68 \%$ of the overall generated PV electrical energy. Hence, only $32 \%$ of the generated PV electrical energy has been utilized. Since this excess electricity is not utilized for the load demand, the municipality can sell it into the Eskom utility grid to generate more revenue.

\subsection{RESULTS FOR A WIND SYSTEM}

For this study, the wind data was collected from one of the South African Weather Services station in Fauresmith (Free State). This town is located $54.5 \mathrm{~km}$ away from Koffiefontein. The wind speed data was collected at different times of the day, this data can help to suggest if a wind renewable energy system 
would be able to supplement the current energy needs of the two towns. Figure 6 indicates the wind speed data obtained at 20:00 pm. Data collected at 20:00 pm was chosen because when most of the people are back from work and schools (between 17:00 pm and 21:00 pm), the peak load demand takes place. The annual average wind speed is $1.53 \mathrm{~m} / \mathrm{s}$ at an anemometer height of $10 \mathrm{~m}$.

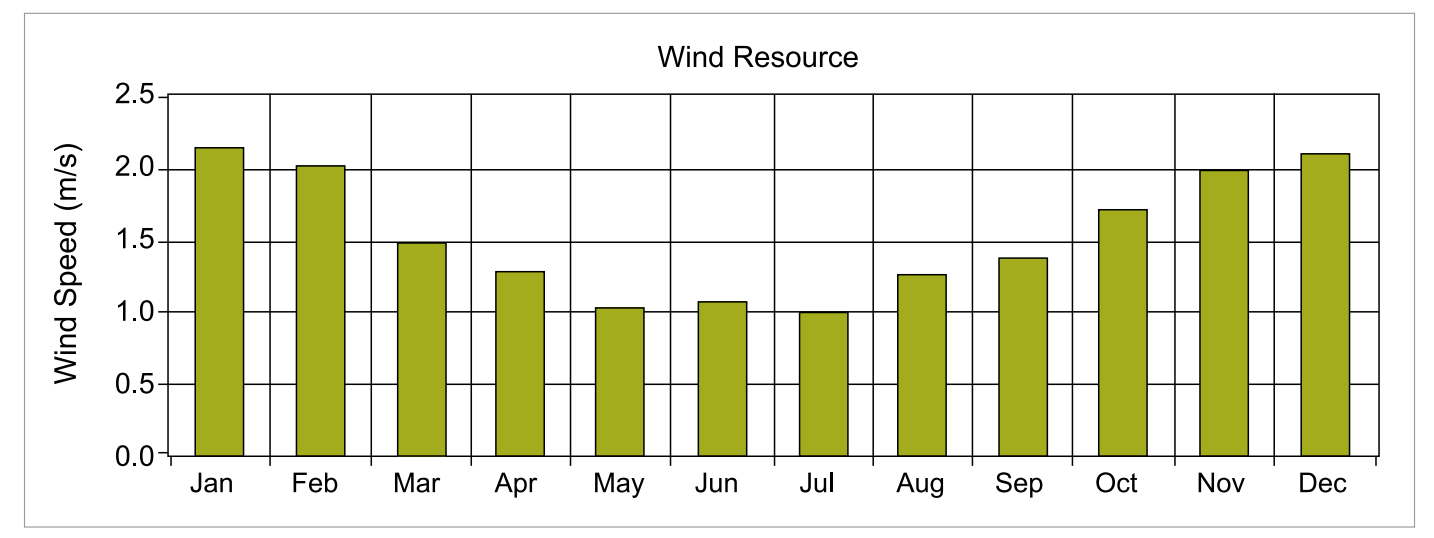

Figure 6. Wind speed data obtained at 20:00 pm from Fauresmith.

Source: own elaboration.

Figure 7 shows the proposed battery-based wind turbine system to be used to supply an averaged sized home in Koffiefontein. This system indicates the primary load of $20 \mathrm{kWh} / \mathrm{d}$ which is used as the electricity consumption input for an average house in Koffiefontein. During Homer simulation, wind turbine system sizes were considered in steps of $10 \mathrm{~kW}$ integer values ranging from 0 to 23 wind turbines. The capital cost of the generic $10 \mathrm{~kW}$ was assumed to be $\mathrm{R} 465320$ (\$307 85) and the O\&M of the system was taken as $2 \%$ of the capital (Koko, 2014). The lifetime of the system was assumed to be 25 years. The following individual sizes were considered for the Trojan T-105 battery: steps of one Ah integers from 3501-3520 Ah. The same capital cost of the battery used for the PV system was considered.

Figure 8 indicates the yearly electricity production results of the battery-based wind turbine system. This system has an electricity production of $1907 \mathrm{kWh}$ /year. This has resulted in an excess electricity of 3.26 
$\mathrm{kWh} /$ year $(0.171 \%)$ with an unmet electricity load of $5.21 \mathrm{kWh} /$ year. This system consists of $170 \mathrm{~kW}$ wind turbine systems and 7012 Trojan T-105 batteries which are connected in 2 batteries per string.

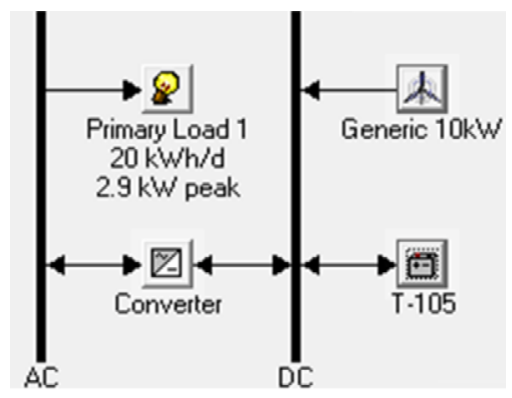

Figure 7. Proposed wind turbine system to supply 1 house in Koffiefontein.

Source: own elaboration.

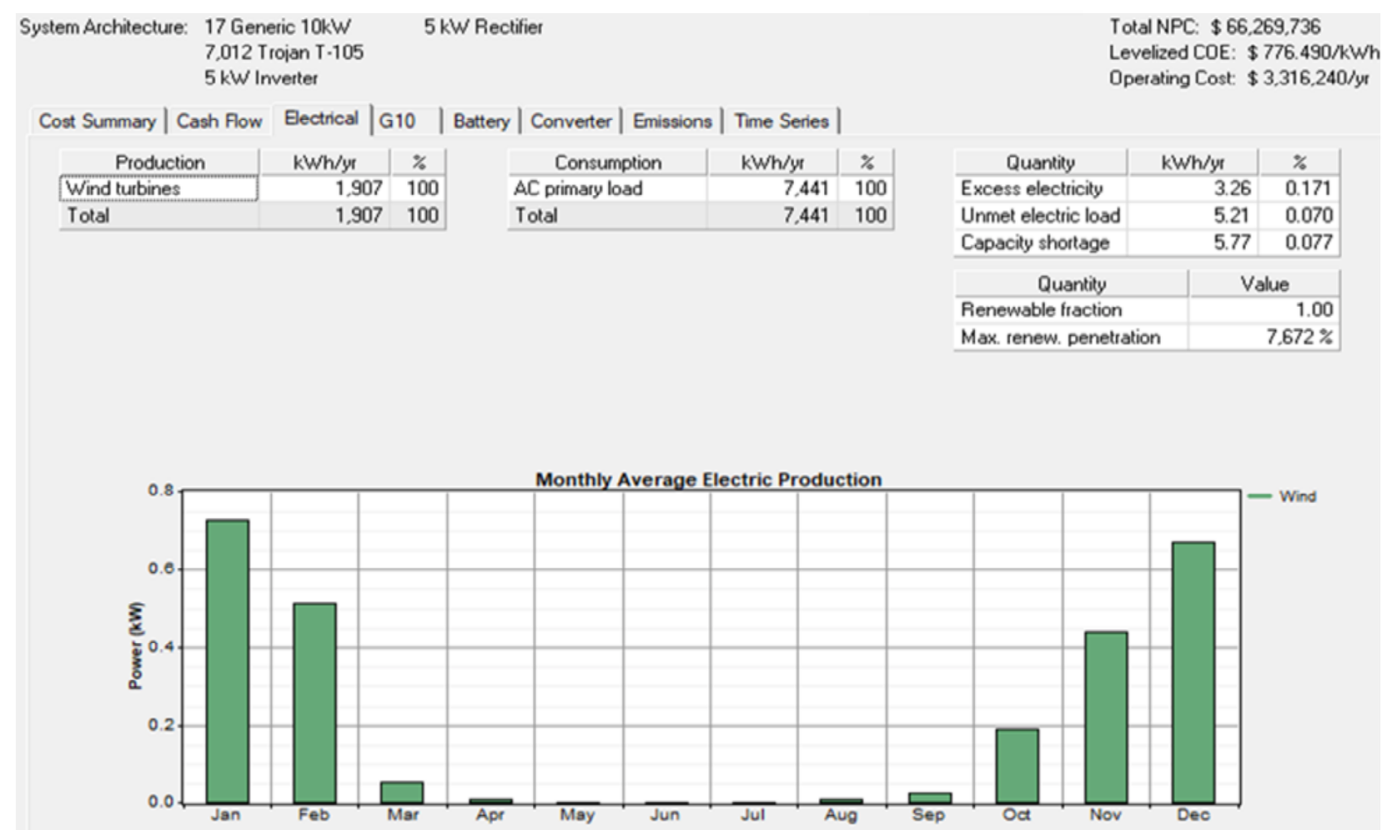

Figure 8. Yearly electricity production of the wind turbine system.

Source: own elaboration. 
Before deciding which system to install for houses in Koffiefontein, payback period of each system suggested by Homer for Koffiefontein houses is determined. To determine the payback period of the municipality, revenue collect from household electricity sales, total cost of the PV system which is R 649 883554 (\$ 42995649 ) for 2038 houses is used and total cost of the wind turbine system which is R 57 538299664 (\$380 067671 2) for 2038 houses is also used.

An averaged sized home in Koffiefontein requires $16 \mathrm{~kW}$ PV panels and $170 \mathrm{~kW}$ wind turbine system to meet its load demand. To determine the size of the PV panels and wind turbine system required to meet the load demand of the total number of houses which is 2038, total number of houses which is 2038 is multiplied by the $16 \mathrm{~kW}$ PV panels and $170 \mathrm{~kW}$ wind turbine system respectfully, this gives a total of 32 $608 \mathrm{~kW}$ PV panels and the wind turbine size is $346460 \mathrm{~kW}$. Equation 2 is used to calculate the payback period of the municipality for both the battery-based wind turbine system and battery-based solar PV system for 2038 houses. The payback period for the battery-based solar PV system is 45.3 years, this is the maximum period which can be reduced if the municipality wishes to sell the excess energy produced back to the national energy supplier in the country.

Cost of the system for the battery-based solar PV system is R 649883554 (\$42 995 649) and for the battery-based wind turbine system is R 57538299664 (\$380667 671 2), these amounts are taken as the initial investment respectfully. Revenue collected in 2016 which is R 6893384 (\$456 059.49) and revenue collected in 2017 which is R 7437498 (\$ 492 057) is combined and taken as cash inflow per period.

Payback period $=\frac{\text { Initial Investment }}{\text { Cash inflow per period }}$

Payback period $($ Solar PV $)=\frac{649883554}{6893384,83+7437498,1}=45.3$ years

Payback period (wind turbine) $=\frac{57538299664}{14330882,93}=4014.10$ years 


\section{CONCLUSIONS}

The main aim of this study was to investigate alternative power generation for local municipalities in order to enable more autonomy and that can help to reduce the pressure placed on the National Gird. To meet the load demand of 2038 houses in Koffiefontein a battery-based solar PV system of size 32608 $\mathrm{kW}$ is required, or a battery-based wind turbine of size $346460 \mathrm{~kW}$ is required. The initial cost of the battery-based solar PV system is R 649883554 (\$ 42995 649) while the initial cost of the battery-based wind turbine system is R 57538299664 (\$380667 671 2).

The cost of energy for the PV system suggested for Koffiefontein houses is R $6.10 / \mathrm{kWh}(\$ 0.40)$ with the yearly electricity production of $27661 \mathrm{kWh}$. The wind turbine system has the cost of energy of $\mathrm{R}$ $776 / \mathrm{kWh}(\$ 51.34)$ with the yearly electricity production of $1907 \mathrm{kWh}$. The PV system has high excess electricity of $18817 \mathrm{~kW}$ while the wind turbine system has an excess electricity of $326 \mathrm{~kW}$.

After performing the payback calculations, the battery-based solar PV system indicated to be the best renewable energy system to be used in Koffiefontein. The cost of energy for the system is cost effective for municipal customers. The municipality will collect more revenue after paying off the system. The payback period maybe reduced if the municipality wishes to sell the excess energy produced back to the national energy supplier in the country.

The municipality should consider doing an energy audit at least every two years to make sure that they are aware of any energy loses so that it can be addressed before it affects revenue collection of the municipality. The municipality should consider installing battery-based solar PV systems for the businesses also so that they may have excess to electricity during load shedding and reduce the pressure on placed on the national grid during high energy demanding hours of businesses.

This study does not include hydro power systems, biomass and geothermal renewable energies. This research is only focused on the electricity sales of one municipality, it does not include electricity loses 
due to tampered meters. Renewable energy alternatives such as solar and wind are gaining momentum and will help in providing electricity to future new developments.

\section{REFERENCES}

Alfreds, D. (2018, October 29). Revealed: Here's where the worst air pollution is in SA. https://www.news2. $\mathrm{com} / \mathrm{amp} / \mathrm{news} 24$ /green/news/revealed-heres-where-the-worst-air-pollution-is-in-sa-20181029

Belu, D. R. (2014). Teaching renewable energy system designs and analysis with Homer. In 121st ASEE Annual Conference and Exposition. Indianapolis. https://www.asee.org/file.server/papers/ attachment/file/0004/5010/ASEE-2014-Teaching_Renewable_Energy_System_Design_With_ HOMER.pdf

Coetze, D., \& Mart-Mari, E. (2016). The impact of load shedding on the construction industry in South Africa. In 9th cidb Postgraduate Conference. Cape Town, South Africa. https://openbooks.uct. ac.za/uct/catalog/download/cidb/7/210-2?inline=1

Davidson, D. O. (2010). Recomendation to the World Bank Group on leading to South Africa for Eskom Investmentsupport project that include a large coal burning power station at Medupi. External peer review report on Eskom, 1-6. https://www.climateinvestmentfunds.org/sites/default/ files/expternal $\% 20$ peer $\% 20$ review\%20report $\% 20$ on $\% 20$ Eskom.pdf

Eskom. (2018, February 8). Eskom holdings SOC ltd. https:/ /www.eskom.co.za

Garni, H. Z. (2017). Optimal design and analysis of grid-connected photovoltaic under different tracking systems using Homer. Energy convertion and management, 155(1), 1-57. https://dx.doi.org/10.1016/j. enconman.2017.10.090

Koko, S. (2014). Micro-hydrokinetic for remote rural electrification. International journal of electrical, Robotics, Electronics and Communication Engineering, 8(11), 1384-1388. https://doi.org/10.1016/j. epsr.2015.04.018 
Nehrir, N. (2011). A review of hybrid Renewable/Alternative energy systems of Electric Power Generation Configuration, Control and Application. IEEE Transactions on sustainable energy 2(4), 393-399. http://dx.doi.org/10.1109/TSTE.2011.2157540

Niselow, T. (2019, March 24). Fin24. Load shedding through the years and how Eskom has struggled to keep the lights on. https://m.fin24.com

Palyi, A. (2015). The contribution of the state audit office to good governance and renewable of accounting. Public Finance Quarterly, State audit office of Hungary, 60(4), 1. https://www.asz.hu/ storage/files/files/public-finance-quarterly-articles/2015/a_palyik_2015_4.pdf

Sen, R. (2013). Off-grid Electricity generation with renewable energy technology in India: An application of Homer. Renewable energy, 62(3), 1-15. http://dx.doi.org/10.1016/j.renene.2013.07.028

South African Government. (2011). Local government budgets and expenditure review. http://www.gov. za/2011-local-government-budgets-and-expenditure-review

Swart, A. J. (2018). Final pass rate fluctuations of power engineering students may be related to load shedding and not load shifting. International Conference on Multidisciplinary Research, Mauritius. https:// www.researchgate.net/publication/326380796_Final_Pass_Rate_Fluctuations_of_Power_ Engineering_Students_May_Be_Related_to_Load_Shedding_and_not_Load_Shifting 
